\title{
Isolation of a Coxsackie virus group B, type 5, from the heart of a fatal case of myocarditis in an adult
}

\author{
MAURICE LONGSON, F. M. COLE 1 , AND DEREK DAVIES \\ From the United Manchester Hospitals, Manchester
}

SYNOPSIS The cause of a fatal case of myocarditis in an adolescent male was established at necropsy by the isolation of Coxsackie virus group B, type 5, from myocardium and bowel. An antibody을 assay on a single serum is reported. This is believed to be a first report and its significance is assessed.

The myocardium may be involved in many viral diseases (Woodward, McCrumb, Carey, and Togo, 1960). The prognosis is variable, especially when associated with an enterovirus. These small, acidstable RNA viruses are widely present; they are commonly excreted by symptomless carriers and, although their virulence for man is extremely variable, they may cause a wide variety of clinically recognizable diseases, including carditis. Jungeblut (1950) isolated polio virus from the heart, and the role of Echo viruses and Coxsackie viruses group $\mathbf{A}$ in cardiac disease is admirably reviewed by Kibrick (1964). It is, however, the undoubted role of the Coxsackie viruses of group B in neonatal myocarditis (Montgomery, Gear, Prinsloo, Kahn, and Kirsch, 1955) which has focused most attention (Gamba, Dolivo, and Bozic, 1966; Jennings, 1966), but it has become increasingly clear that the heart of adults may also be involved. Pericarditis has frequently been described during Coxsackie B virus infection (Fletcher and Brennan, 1957; Bell and Meis, 1959; Lewes and Lane, 1961; Smith, 1966) and, as in infants, myocarditis may also occur. Unfortunately it has proved difficult to establish the exact aetiology of these adult cases. Cardiac tissue has rarely been available for virus isolation and diagnosis has therefore been based on faecal excretion of the virus or serological evidence of recent infection (Null and Castle, 1959; Connolly, 1961; Sun and Smith, 1966; Bennett and Forbes, 1967; Sainani, Krompotic, and Slodki, 1968). Such bases for diagnosis are not entirely satisfactory and there has been speculation as to the actual mechanism of the cardiac damage (Helin, Savola, and Lapin-

${ }^{1}$ Present address: McMarker University, Hamilton, Canada.

Received for publication 20 February 1969.

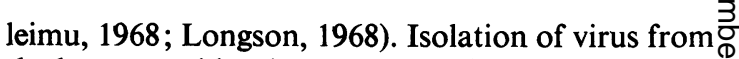
the heart provides the strongest evidence that pathological changes may be the direct result of virus replication in cardiac tissue.

A number of recent workers have succeeded in isolating Coxsackie virus from the adult heart either at necropsy (Sanyal, Mahdavy, Gabrielson, Vidone, and Browne, 1965; Cossart, Burgess, and Nash, 1965) or by biopsy (Sutton, Harding, True- $\frac{\Phi}{\Phi}$ heart, and Clark, 1967) but their reports do not $\stackrel{2}{F}$ appear to have received the attention they deserve.

\section{CASE REPORT}

A 15-year-old boy was admitted on 14 May 1968 with? extreme orthopnea. Three episodes of tonsillitis had resulted in tonsillectomy in 1958 . Ten days after operation. he developed muscle pains, when some tenderness in the calf and thigh muscle but no joint symptoms, was noted. This settled quickly and no throat swabs were taken. He응 then remained well until two days before admission, when he became febrile with headache, sore throat, followedo by nausea and vomiting. Next morning he awoke with a dry cough and mild chest pain, unaffected by breathing. N Twenty-four hours later breathlessness developed and rapidly increased in severity.

On examination he was cyanosed with mildly inflamed $\omega$ fauces: blood pressure $100 / 70 \mathrm{~mm} \mathrm{Hg}$ and pulse $120 / 0$ minute, regular. The jugular venous pressure was normal, there was no oedema, heart sounds were rapid but normal, and the heart was not enlarged or displaced.? Respiration was 60/minute. Chest expansion and per- 0 cussion were normal. Auscultation showed showers of fine crepitations over both lung fields and a chest radio- $\mathbb{\mathbb { D }}$ graph widespread patchy opacities. Six hours after $\frac{?}{\mathbb{D}}$ admission the pulse rate had risen to 140 /minute, but 0 otherwise there was little change in his condition. The next day the patient deteriorated: he began to bring up 0 
TABLE I

\begin{tabular}{|c|c|c|c|c|c|c|}
\hline \multirow[b]{2}{*}{$\begin{array}{l}\text { Astrup } \\
\text { Reading } \\
\text { No. }\end{array}$} & \multicolumn{4}{|c|}{ ASTRUP READINGS } & \multirow[b]{2}{*}{$\begin{array}{l}\text { Buffer } \\
\text { Base } \\
\text { (m-equiv/l) }\end{array}$} & \multirow[b]{2}{*}{$\begin{array}{l}\text { Base } \\
\text { Excess } \\
\text { (m-equiv/l) }\end{array}$} \\
\hline & $\begin{array}{l}\mathrm{PO} \\
(\mathrm{mm} \mathrm{Hg})\end{array}$ & $\begin{array}{l}\mathrm{PCO}_{2} \\
(\mathrm{~mm} \mathrm{Hg})\end{array}$ & $\mathrm{p} H$ & $\begin{array}{l}\text { Standard } \\
\text { Bicarbonate } \\
\text { (m-equiv/l) }\end{array}$ & & \\
\hline $\begin{array}{l}1 \\
2 \\
3 \\
4 \\
5\end{array}$ & $\begin{array}{l}-\overline{33} \\
36 \\
\frac{50}{5}\end{array}$ & $\begin{array}{l}38 \\
31 \\
40 \\
95 \\
67\end{array}$ & $\begin{array}{l}7 \cdot 29 \\
7 \cdot 26 \\
7 \cdot 27 \\
7 \cdot 12 \\
7 \cdot 29\end{array}$ & $\begin{array}{l}18 \\
15 \cdot 2 \\
17.6 \\
20.6 \\
20.6\end{array}$ & $\begin{array}{l}40 \\
35 \cdot 5 \\
39 \cdot 5 \\
44 \cdot 0 \\
51 \cdot 0\end{array}$ & $\begin{array}{r}8.0 \\
-12.2 \\
-8.5 \\
-4.2 \\
+2.0\end{array}$ \\
\hline
\end{tabular}

copious amounts of frothy, orange-coloured sputum and the jugular venous pressure was found to be raised (Table I, Astrup 1). Within the next two hours visible dilatation of the jugular veins had reached the angle of the jaw, the patient was deeply cyanosed, and he was sweating profusely. The blood pressure was maintained, but the pulse was weak (Table I, Astrup 2). Continuous oxygen was administered for $\mathbf{3 0}$ minutes (Table I, Astrup 3), before he was transferred to the Respiratory Care Unit for intubation and intermittent positive pressure respiration on a Bird respirator. An infusion of molar bicarbonate was set up. During intubation the patient suffered cardiac arrest. Intubation was quickly achieved and immediately orange-coloured fluid poured out of the tube. External cardiac massage was applied for three minutes until spontaneous contractions occurred, when he had a grand mal convulsion (Table I, Astrup 4). Before cardiac arrest the electrocardiogram had shown tachycardia but was otherwise normal, but now the QRS complexes were widened and the $T$ waves inverted in the pattern of a left bundle branch block. After $\mathbf{3 0}$ minutes on the Bird respirator, however, the ECG returned to normal (Table I, Astrup 5).

Ventilation became increasingly difficult as a result of copious flow of the pulmonary oedema fluid, which necessitated frequent drainage of the tube and tracheal toilet. At no time did diuretic therapy, parenteral or oral, affect the degree of pulmonary oedema.

After 90 minutes the heart rate gradually slowed over a period of three minutes and then converted from sinus rhythm to complete heart block with a ventricular rate of 60 per minute. The patient lost consciousness. External cardiac massage was recommenced, but after one hour, ventilation became impossible because of the large quantities of oedema fluid. The patient died 29 hours after admission, on the fourth day of illness.

\section{NECROPSY FINDINGS}

The pathological findings were confined to the heart and lungs.

HEART The heart weighed $350 \mathrm{~g}$. The pericardial sac contained $110 \mathrm{ml}$ of clear, straw-coloured fluid but no other evidence of pericarditis. At the apices of both ventricles there was recent mural thrombus and the left ventricle was dilated. The myocardium throughout was pale and soft. The endocardium and the valves showed no abnormality. The coronary arteries appeared normal. Microscopically (Fig. 1) the changes were generally present but were more severe in the ventricles. The predominant feature was extensive muscle fibre necrosis. The necrotic fibres were often adjacent to fibres which appeared normal. The sarcoplasm of the affected cells was eosinophilic and granular with loss of striations. Many fibres showed cytoplasmic vacuolation and the nuclei were often grossly pyknotic or absent. There was active myoclasis. Throughout the heart muscle and, particularly in relation to the necrotic areas, there was a diffuse lymphocytic cell infiltrate with occasional plasma cells and neutrophil polymorphs. Inflammatory oedema separated many muscle fibres. There was a trivial collection of lymphocytes in the pericardium and endocardium. There was no sign of acute rheumatic carditis, in particular no Aschoff bodies. Some endocardial thickening noted in the atria consisted of endomyocardial fibrosis up to about $40 \mu$ thick (Fig. 2). Also scattered throughout the whole myocardium were small foci of established fibrosis (Fig. 3). The appearance of the foci gave no clue as to their cause. As there were no areas which showed stages between the acute and these chronic lesions, it would seem that the latter were the result of an earlier distinct episode of inflammation and necrosis.

LUNGS The right pleural cavity contained $950 \mathrm{ml}$ and the left $200 \mathrm{ml}$ of fluid similar to that seen in the pericardial sac. The lungs $(\mathrm{R}, 1,300 \mathrm{~g} ; \mathrm{L}, 1,600 \mathrm{~g})$ showed diffuse, severe pulmonary oedema but no evidence of pneumonic consolidation. Microscopically, the pulmonary oedema was confirmed and there was an occasional hyaline membrane. A few macrophages were present in many of the alveoli. There was no sign of inflammation.

\section{LABORATORY INVESTIGATIONS}

The following specimens were submitted to the laboratory for virus isolation: (1) a rectal swab collected shortly after admission but faecal material was not recognizable on the swab; (2) small bowel content collected at necropsy; 


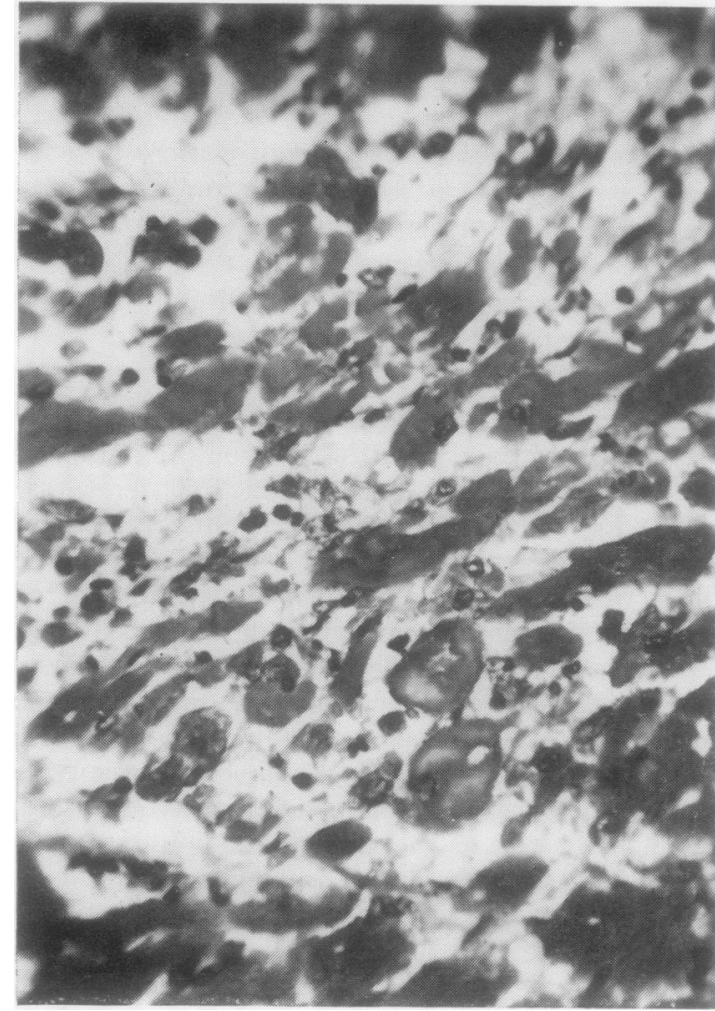

FIG. 1.

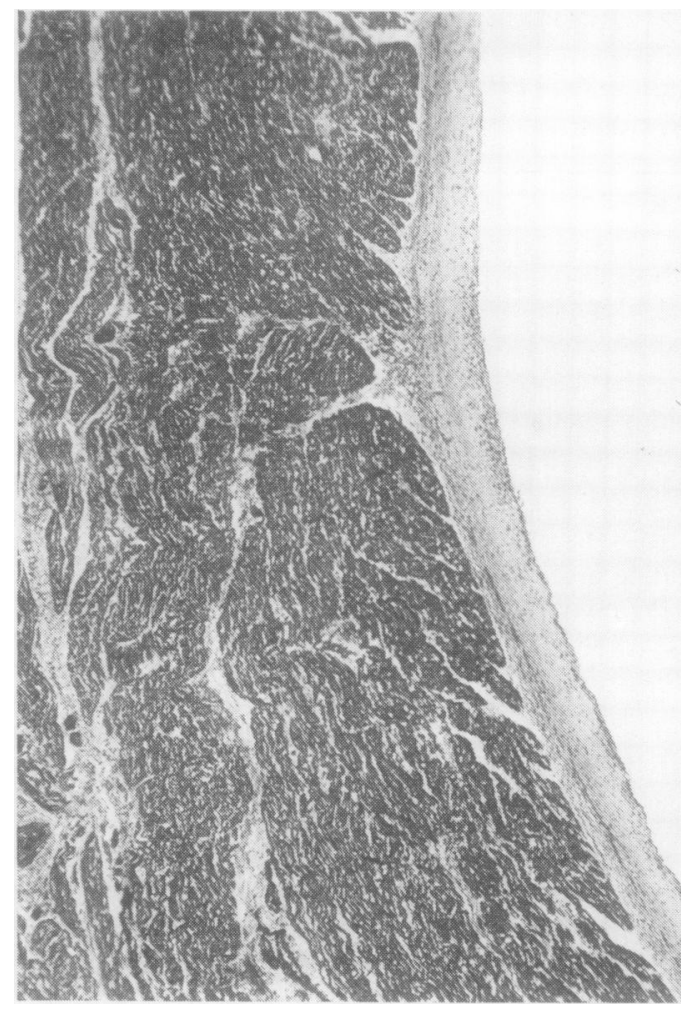

FIG. 2.

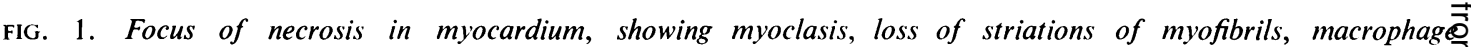
activity, and round cell infiltration $(\times 350)$. FIG. 2. Atrial wall showing endocardial thickening $(\times 90)$.

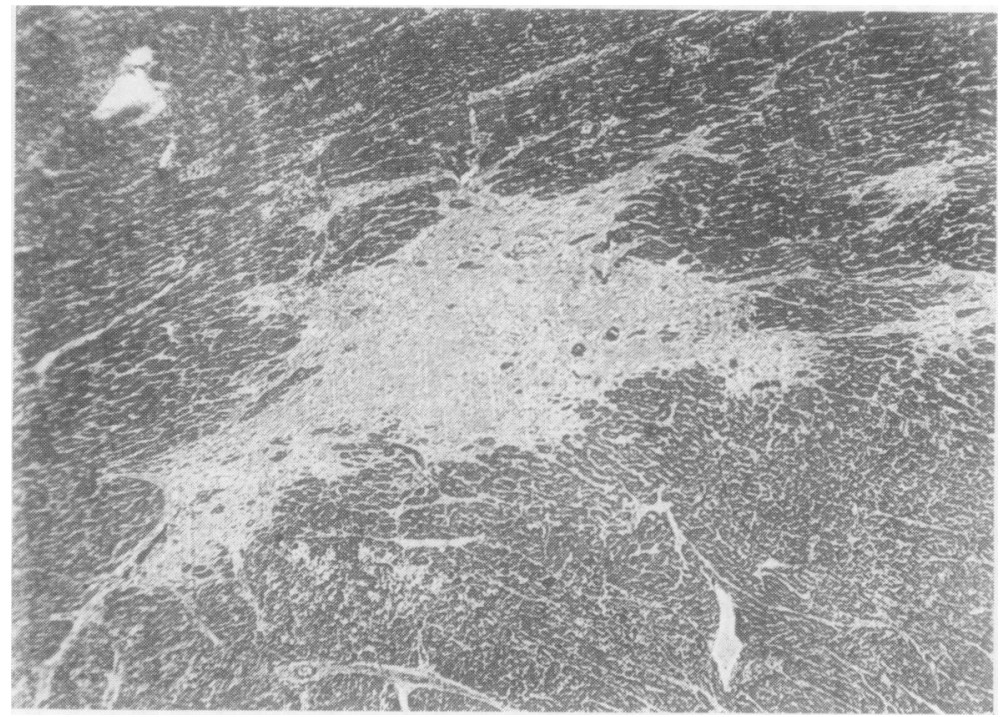
myocardium $(\times 90)$. 
(3) necropsy specimens of both lower lobes of lung (30 $\times$ $30 \times 30 \mathrm{~mm}$ ); (4) necropsy specimen of left ventricular myocardium $(15 \times 15 \times 25 \mathrm{~mm})$.

The small bowel content and the rectal swab were suspended in 10 volumes of a transport solution containing Eagle's minimum essential medium, $10 \%$ rabbit serum, $0.01 \%$ kanamycin, $100 \mathrm{iu} / 100 \mathrm{ml}$ penicillin, and $0.01 \%$ streptomycin. The suspensions were then violently agitated on a mechanical shaker and submitted to one cycle of rapid freezing and thawing. Debris was removed by centrifuging for 15 minutes at $3,000 \mathrm{rpm}$ and the supernatant used for inoculation into tissue culture.

Immediately after removal at necropsy the heart and lung tissues were plunged into boiling water for approximately 30 seconds. A sterile knife was used to cut off and discard surface tissue and preserve for virus isolation the raw centre of each specimen. This technique effectively reduced contamination. The tissues were ground in a Ten Broeck grinder and suspended in the transport solution described above. One drop of each treated specimen was inoculated into stationary and rolling cultures of secondary Rhesus monkey kidney cells, secondary human amnion cells, HeLa cells, and HEp 2 cells. All cultures were incubated with suitable maintenance medium at $33.5^{\circ} \mathrm{C}$ for 15 days at which time all negative tubes were passaged into fresh monolayers for incubation for a further 15 days.

\section{RESULTS}

The rectal swab and the pulmonary tissues failed to yield any cytopathogenic agent and were finally discarded.

Cultures inoculated with myocardial and bowel material showed a typical enterovirus cytopathic effect after three to five days' incubation. Passage of each isolate was readily accomplished and the agent was identified by neutralization against a standard panel of specific reference enterovirus rabbit antisera. Neutralization of the isolates was effected exclusively by the Coxsackie virus group $B$, type 5 , antiserum. In control tests this antiserum failed to show any effect on the infectivity of a known Coxsackie virus B4, whereas it completely neutralized $10^{6} \mathrm{TCID}_{50}$ of a reference strain of Coxsackie virus B5.

The virus from the original materials was again isolated by inoculating $0.2 \mathrm{ml}$ of prepared specimens subcutaneously, intraperitoneally, and intracranially into litters of mice. Animals inoculated with the heart or bowel material died within eight days. Representative carcases were ground in transport solution, debris was centrifuged, and passage of supernatant fluid in dilutions ranging from $10^{-1}$ to $10^{-4}$ was effected into further litters of day-old mice. The mice inoculated with the concentrated material died within five days. Intermediate dilutions caused spastic paralysis with histological evidence of muscle necrosis, panniculitis, and myocarditis, typical of that produced by the Coxsackie B viruses.

A specimen of serum obtained from the patient about two hours before death was tested against a reference strain of Coxsackie virus B5 and against the new isolate. Serial two-fold dilutions were assayed; in each case the neutralizing antibody level was less than $1: 8$.

\section{DISCUSSION}

Reports of fatal Coxsackie virus myocarditis in adults are rare. It is reasonable to suggest that this does not reflect the true frequency of the condition and that many cases are missed and classified as idiopathic or Fiedler's myocarditis. The case described in this report presented as typical acute idiopathic myocarditis. It is noteworthy that Cossart and her colleagues (1965) and Friedberg (1966) made similar comments concerning the ECG, and that in monkeys Lou, Wenner, and Kamitsuka (1961) have showed that the ECG is normal in Coxsackie virus myocarditis.

The pathological features of the heart in our case were similar to those described in epidemic neonatal myocarditis. The dilatation of the ventricles, the myocardial pallor with mural thrombosis, together with extensive necrosis and variable mononuclear cell infiltrate, are all features which have been repeatedly emphasized. The older fibrotic foci in the myocardium were considered to be the result of a previous quite distinct episode, the nature of which it is impossible to determine. Previous rheumatic carditis, despite the lack of specific histological stigmata, cannot be ruled out, especially in view of the history of tonsillitis and limb pains.

The absence of specific neutralizing antibody is not surprising because of the short history. It does, however, confirm the patient's susceptibility to a Coxsackie virus B5 infection.

Two views have been expressed about the pathogenesis of viral myocarditis: one that the heart is damaged by an autoimmune process, the other that the myocardial damage is the result of the direct invasion by the virus (for references see Longson, 1968). The position is now perhaps becoming clearer.

The pathogenicity of Coxsackie virus of group B for the hearts of mice is well known (Dalldorf, 1965; Rabin, Hassan, Jenson, and Melnick, 1964). Similarly Lou and his colleagues (1961) have shown that Coxsackie B viruses will directly cause myocarditis in monkeys, and Burch, Sun, Colcolough, Sohal, and DePasquale (1967) have demonstrated that the simian endocardium is also involved, resulting in chronic valvulitis. It is particularly significant that such diseases are caused in primates. 
We have, for the first time, established that Coxsackie virus B5 will directly cause an extremely severe myocarditis in man. Epidemics of these virus diseases occur in the United Kingdom (British Medical Journal, 1967) and may produce cardiac complications (Bell and Grist, 1968). It is therefore important to study the long-term sequelae and to establish the prognosis of viral myocarditis. It is reasonable to suggest that Coxsackie viruses may also be shown to have a role in the aetiology of nonrheumatic valve disease in man. In any case the diagnostic rate must be improved but, unfortunately, it is not possible to recommend the myocardial biopsy technique used by Sutton and his colleagues (1967) for routine use.

In the meantime, two aspects of viral infection of the heart deserve comment. First, exercise may be an aggravating factor. During the early stages of poliomyelitis in man exercise causes severe paralysis (Horstmann, 1950), and during Coxsackie virus infection in mice it caused an increased yield of virus (Tilles, Elson, Shaka, Abelmann, Lerner, and Finlond 1964). The patient described by Sutton and his colleagues (1967) indulged in excessive swimming in the early stages of his illness.

Secondly, there are reasons for withholding steroids. Cortisone inhibits the production and action of interferon, and sometimes in viral diseases, cortisone has a disastrous effect (Spirito and Braito, 1966; Longson and Pitkeathly, 1969). In monkeys, steroids increase the virulence of polio virus (Coid, Tobin, and Beswick, 1960), and in mice they increase the severity of myocarditis following Coxsackie virus infection (Rabin et al, 1964).

Our thanks are due to Professor T. S. L. Beswick and Dr J. B. L. Howell for their patronage during the preparation of this report, and to Mr Andrew Bailey for technical assistance. Acknowledgements are also due to Dr C. M. P. Bradstreet, of the Standards Laboratory,
Colindale, and to Dr F. T. Perkins, of the Nationati Institute of Medical Research for materials used in thiş? study.

\section{REFERENCES}

Bell, E. J., and Grist, N. R. (1968). Scot. med. J., 13, 47.

Bell, J. F., and Meis, A. (1959). New Engl. J. Med., 261, 126.

Bennett, N. McK., and Forbes, J. A. (1967). Amer. Heart J., 7\$ 435. British Medical Journal, (1967). 4, 570.

Burch, G. E., Sun, S. C., Colcolough, H. L., Sohal, R. S., and DePasquale, N. P. (1967). Ibid, 74, 13.

Coid, C. R., Tobin, J. O'H., and Beswick, T. S. L. (1960). J. Patkw Bact., 79, 325.

Connolly, J. H. (1961). Brit. med. J., 1, 877.

Cossart, Y. E., Burgess, J. A., and Nash, P. D. (1965). Med. J. Aust. $1,337$.

Dalldorf, G. and Melnick, J. L. (1965). In Viral and Rickettsia Infections of Man, 4th ed., edited by F. L. Horsfall, Jr., and I. J. B. Tamm, p. 474, Lippincott, Philadelphia, Pitmanor London.

Fletcher, E., and Brennan, C. F. (1957). Lancet, 1, 913.

Friedberg, C. K. (1966). Diseases of the Heart, 3rd ed., Saunders, Philadelphia.

Gamba, D., Dolivo, G., and Bozic, C. (1966). Rev. med. Suiss Romande, 86, 206.

Helin, M., Savola, J., and Lapinleimu, K. (1968). Brit. med. J., 3, 9 \\}

Horstmann, D. M. (1950). J. Amer. med. Ass., 142, 236

Jennings, R. C. (1966). J. clin. Path., 19, 325.

Jungeblut, C. W. (1950). J. Pediat., 37, 109.

Kibrick, S. (1964). Progr. med. Virol., 6, 27.

Lewes, D., and Lane, W. F. (1961). Lancet, 2, 1385.

Longson, M. (1968). Brit. med. J., 3, 555.

, and Pitkeathly, D. A. (1969). In preparation.

Lou, T. Y,, Wenner, H. A., and Kamitsuka, P. S. (1961). Arch ges. Virusforsch., 10. 451.

Montgomery, J., Gear, J., Prinsloo, F. R., Kahn, M., and Kirsch Z. G. (1955). $S$. Afr, med. $J, 29,608$.

Null, F. C. Jr., and Castle, C. H. (1959). New Engl. J. Med., 261, 93 బิ

Rabin, E. R., Hassan, S. A., Jenson, A. B., and Melnick, J. L. (1964 Amer. J. Path., 44, 775.

Sainani, G. S., Krompotic, E., and Slodki, S. J. (1968). Medicin (Baltimore), 47, 133

Sanyal, S. K., Mahdavy, M., Gabrielson, M. O., Vidone, R. A., and Browne, M. J. (1965). Pediatrics, 35, 36.

Smith, W. G. (1966). Brit. Heart J., 28, 204.

Spirito, L., and Braito, A. (1966). G. Mal. infett., 18, 763.

Sun, N. C., and Smith, V. M. (1966). New Engl. J. Med., 274, 190.

Sutton, G. C., Harding, H. B., Trueheart, R. P., and Clark, H. (1967). Aerospace Med., 38, 66

Tilles, J. G., Elson, S. H., Shaka, J. A., Abelmann, W. H? Lerner, A. M., and Finlond, M. (1964). Proc. Soc. exp. Bio\% (N.Y.) 117, 777.

Woodward, T. E., McCrumb, F. R. Jr., Carey, T. N., and Togo, (1960). Ann. intern. Med., 53, 1130. 